\title{
PELAKSANAAN PENILAIAN JABATAN FUNGSIONAL GURU SEKOLAH DASAR
}

\author{
Zulfiyatul Lailiyah \\ Program Studi Pendidikan Guru Sekolah Dasar \\ Fakultas Keguruan dan Ilmu Pendidikan \\ Universitas Nahdlatul Ulama Sidoarjo \\ Email : Zulfiyatull@gmail.com
}

\section{Pengantar}

Sampai akhir tahun 1999 ini, pelayanan akan pendidikan dasar sebagai kebutuhan pendidikan masyarakat Indonesia, masih tergolong besar. Dengan kondisi demikian, banyak hambatan dan tantangan yang masih harus dihadapi dan diatasi. Salah satu hambatan yang cukup menonjol dalam penyelenggaraan pendidikan dasar ini, terutama pada tingkat Sekolah Dasar di daerah pedesaan adalah, masalah 'Guru Kelas'.

Nugraha Suharto ( 2003 ) Memberitahukan Sekolah Dasar di daerah pedesaan, umumnya mengalami kekurangan 'Guru Kelas' sehingga alternatif utama dalam mewujudkan produktivitas pendidikan yang maksimal terletak pada upaya bagaimana meluaskan 'Kualitas Kinerja Guru Sekolah Dasar' yang ada, disamping upaya menyediakan Guru Sukarelawan atau Guru Kontrak. Di sisi Lain, Jabatan fungsional Guru Dan Angka Kreditnya, yang sebenarnya ditujukan untuk pembinaan karier Guru dalam hal kenaikan Pangkat, secara tak langsung merupakan sarana untuk memotivasi Guru dalam meningkatkan Kinerjanya. Sebab melihat pada rincian kegiatan Surat Keputusan tersebut, menunjukan adanya hubungan bahwa, semakin banyak point Angka Kredit terkumpul, maka semakin banyak pula aktifitas - aktifitas yang dapat meningkatkan keahlian guru dilakukan oleh para guru atau tingginya Pangkat atau jabatan seorang Guru akan sebanding dengan keahlian yang dimilikinya.

\section{Pelaksanaan Jabatan Fungsional Guru}

Secara garis besar, mekanisme Pelaksanaan Penilaian Jabatan Fungsional

Guru yang dilakukan oleh Pemerintah, berdasarkan Keputusan Menteri Pendidikan dan Kebudayaan Republik Indonesia No. 025/1995 Tentang Petunjuk Teknis Ketentuan Pelaksanaan Jabatan Fungsional Guru dan Angka Kreditnya, dijalankan melalui beberapa tahap yakni:

Pertama, Diawali oleh pengajuan Daftar Usulan Penetapan Angka Kredit (DUPAK) oleh para guru melalui Kepala Sekolah. 
Kedua, Dilakukan penilaian oleh Tim Penilai yang terdiri dari pihak Depdikbud dan para guru yang telah ditetapkan. Tim Penilai terdiri dari dua kelompok yakni: (1) Tim Penilai untuk para guru Golongan IIa sampai IIIa berasal dari tingkat Kabupaten, dan (2) Tim Penilai untuk para guru Golongan IIIb ke atas berasal dari tingkat Propinsi.

Ketiga, Hasil penilaian diajukan kepada Badan Administrasi Kepegawaian Negara (BAKN) yang mana badan ini berperan sebagai fihak yang berwenang mengeluarkan SK kepangkatan.

Keempat, Hasil dari proses penilaian Jabatan Fungsional Guru yang berupa SK kepangkatan selanjutnya dikirim kepada para guru yang bersangkutan. Secara sederhana, mekanisme tersebut dapat digambarkan sebagai berikut: (Bagan: 1)

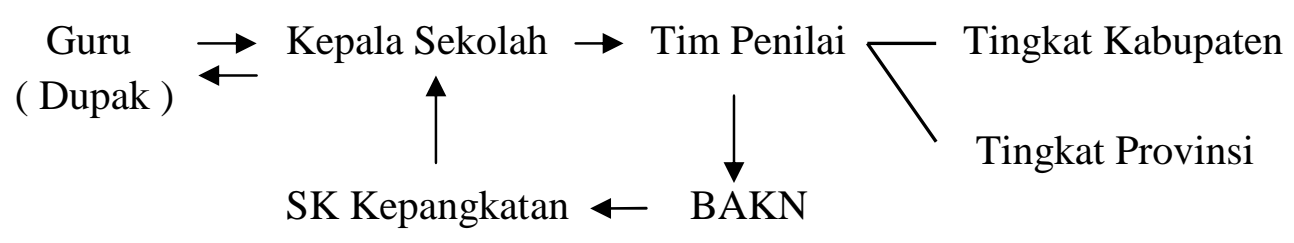

Bagan : 1

Pelaksanaan Penilaian Jabatan Fungsional Guru Yang Dilakukan Pemerintah

Adapun hubungan diantara Pelaksanaan Penilaian Jabatan Fungsional Guru dan Kinerja Guru adalah, semakin banyak seorang Guru mengumpulkan point-point Angka Kredit, berarti semakin banyak pula Rincian Kegiatan yang lakukannya atau kenaikan pangkat atau jabatan yang diperoleh seorang Guru akan sebanding dengan peningkatan kualitas Kinerja Guru. Secara sederhana hal tersebut dapat digambarkan sebagai berikut : (Bagan: 2)

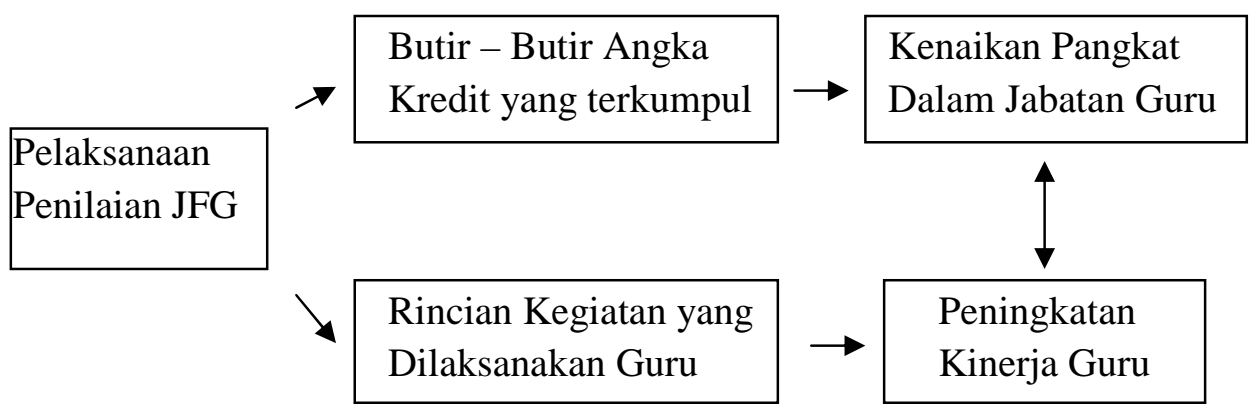


Bagan : 2

Hubungan Antara Pelaksanaan Jabatan Fungsional Guru

Dengan Peningkatan Kinerja Guru

Selanjutnya secara aplikatif hubungan antara Pelaksanaan Jabatan Fungsional Guru (JFG) dengan Abilitas dan Kinerja Guru dapat dijelaskan melalui gambaran sebagai berikut: (Bagan: 3)

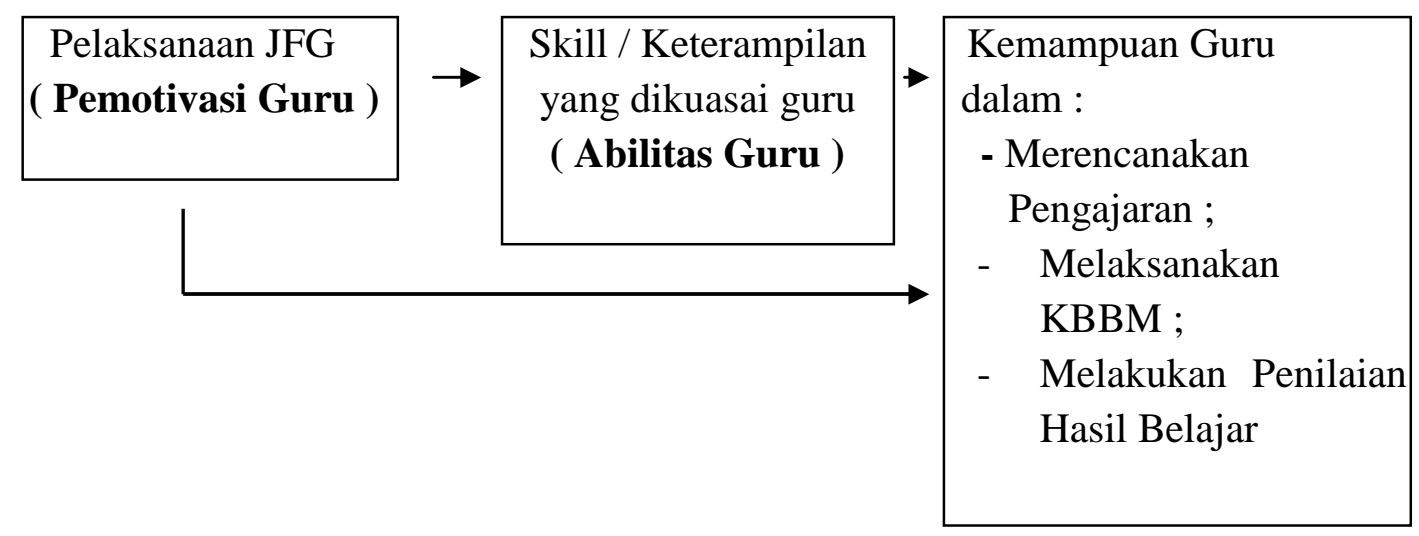

Bagan: 3

Aplikasi Hubungan Pelaksanaan Jabatan Fungsional Guru Dengan Abilitas dan Kinerja Guru

Kerangka pemikiran tersebut didasari oleh teori dasar (Grand Theory) tentang Kinerja (Performance) yang dirumuskan oleh T. R. Mithcell (1978:327), yakni:

\section{Performance $=$ Motivation $\mathrm{X}$ Ability}

Formulasi tersebut di atas, telah teruji dan diuraikan oleh beberapa ahli lainnya seperti oleh Jay Calbraith dan L. L. Cummings, sebagaimana dikutip oleh Wayne K. Hoy dan Cecil G. Miskel (1978), dalam studinya secara umum mendukung anggapan adanya hubungan (relationship) antara motivasi (Motivation) dan Abilitas (Ability) berkaitan dengan kinerja (Performance).

\section{Kutipan}

Kinerja guru adalah wujud perilaku guru dalam Proses Belajar Mengajar yakni, bagaimana seorang guru mempersiapkan pengajaran, melaksanakan kegiatan

belajar mengajar dan menilai hasil belajar. Secara konseptual kinerja guru merupakan pengumpulan dari motivasi dan ability guru.(T. R. Mithcell, 1978:327).

Abiliti Guru dapat diartikan kecakapan profesional guru dalam berbicara menunjuk pada suatu tindakan kependidikan yang berbuah positif bagi proses belajar dan perkembangan pribadi siswa atau individu. Dan bentuk kegiatan 
kependidikan tersebut dapat berwujud keterampilan mengajar (Teaching skills) sebagai pengumpulan dari pengetahuan (Knowledge) yang diperoleh para guru saat di bangku pendidikan. (A. Samana, 1994:51).

Motivasi Guru disini diartikan sebagai faktor-faktor penyebab yang berhubungan dengan sesuatu dalam perilaku guru. Sedangkan pengertian sesuatu yang dimaksud merupakan "dorongan berbagai kebutuhan hidup manusia dari mulai kebutuhan fisik, rasa aman, sosial, penghargaan dan pengaktualan diri." (Maslow, 1970:35), maka dikalangan para guru, Jabatan Fungsional Guru dapat dipandang secara aplikatif sebagai salah satu cara dalam memotivasi (pemotivasi) para Guru untuk meningkatkankeahliannya.

\section{Penutup}

Berdasarkan dari hasil pembahasan dalam pelaksanaan jabatan fungsional guru, maka dapat disimpulkan sebagai berikut :

1. Kinerja guru profesional sekolah dasar di dalam aspek perencanaan pembelajaran secara keseluruhan masuk dalam katagori tinggi dengan presentase sebesar $85,94 \%$. indikator yang di ukur dalam penelitian ini meliputi kerutinan, kemandirian, ketepatan waktu dan pengembangan dalam penyusunan program tahunan, program semester, dan rencana pelaksanaan pembelajaran.

2. Kinerja guru profesional sekolah dasar dalam aspek pelaksanaan pembelajaran secara keseluruhan masuk dalam kategori tinggi dengan presentase $89,38 \%$. Indikator yang diukur dalam penelitian ini meliputi ketepatan dan kesesuaian dalam penggunaan alokasi waktu pembelajaran, strategi / mode pembelajaran, media dan sumber belajar, penyampaian materi pelajaran, dan pengaturan kelas.

\section{Reference}

Abin Syamsuddin Makmun (1996). Analisis Posisi Pendidikan. Jakarta : Depdikbud Biro Perencanaan, Sekretariat Jenderal.

Achmad Sanusi (1991). Studi Pengembangan Model Pendidikan Profesional Tenaga Kependidikan. Bandung : IKIP Bandung.

Badudu, Yus. Dan Zain, H. (1994). Kamus Umum Bahasa Indonesia. Jakarta : PT Gramedia.

Benjamin S. Bloom et. al. (1981). Evaluation to Improve Learning. Mc. Grow Hill Book Company. 
Bob Davis et. al. (1994). Physical Education and The Study of Sport (Second Edition). Mosby: Times Mirror International Publisher Limited.

Castetter, William B. (1996). The Human Resource Function In Educational Administration. New Jersey : A Simon \& Schuster Company.

Depdikbud (1996/1997). Keputusan Menteri Pendidikan Dan Kebudayaan Republik Indonesia Nomor: 025/O/1995 Tentang Petunjuk Teknis Ketentuan Pelaksanaan Jabatan Fungsional Guru Dan Angka Kreditnya. Jakarta : Direktorat Jenderal Pendidikan Dasar Dan Menengah Direktorat Pendidikan Guru Dan Tenaga Teknis. 
